PRZEGLĄD NAUK HISTORYCZNYCH 2020, R. XIX, NR 1

http://dx.doi.org/10.18778/1644-857X.19.01.03

\title{
Dlaczego Szwedzi przegrali bitwę pod Połtawą? Natura przeciwko armii szwedzkiej w kampaniach 1708 i 1709 roku
}

Streszczenie. W artykule przedstawiono przebieg działań podejmowanych przez armię szwedzką w latach 1708-1709. Obie kampanie skierowane były przeciwko Rosji, a celem strategicznym nakreślonym przez władcę Szwecji - Karola XII było zajęcie Moskwy. W ostatecznym rozrachunku, u schyłku 1708 r. wojska szwedzkie znalazły się jednak nie na przedpolu stolicy carów, a na Ukrainie Zadnieprzańskiej. W roku następnym Szwedzi stoczyli bitwę pod Połtawa, która zakończyła się ich klęską. Autor próbuje odpowiedzieć na pytanie, dlaczego tak się stało? Omawiając drogę Karola XII na połtawskie pole bitwy, zwraca uwage przede wszystkim na czynniki naturalne i obiektywne (pogoda, ukształtowanie powierzchni, przeszkody naturalne itd.), na które król Szwecji nie miał żadnego wpływu. Zdaniem autora to właśnie te czynniki w dużym stopniu wpłynęły na to, że szwedzka armia stanęła do walki pod Połtawą znacznie osłabiona i z niewielkimi szansami na zwycięstwo.

Słowa kluczowe: Karol XII, wielka wojna północna, kampanie 1708 i 1709 roku, wyprawa na Moskwę, bitwa pod Połtawa, pogoda i warunki naturalne.

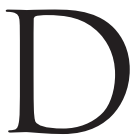

nia 9 lipca 1709 r. armia szwedzka została pokonana przez wojska rosyjskie w bitwie pod Połtawa. Był to punkt zwrotny w wielkiej wojnie północnej. Szwedzi ostatecznie utracili inicjatywę strategiczna i zostali zmuszeni do przejścia do działań defensywnych, a ich władca - Karol XII, odcięty od własnego kraju, przez kilka kolejnych lat został zmuszony do pozostania na terytorium Turcji. W czasie nieobecności króla w ojczyźnie szala zmagań

* Wydział Filozoficzno-Historyczny, Instytut Historii, Katedra Historii Nowożytnej, e-mail: zbigniew.anusik@uni.lodz.pl 
wojennych przechyliła się już wyraźnie na korzyść antyszwedzkiej koalicji. Przegrana w ostatecznym rozrachunku wojna oznaczała też koniec szwedzkiego imperium. Szwecja definitywnie utraciła status mocarstwa, a rola nowego hegemona w Europie Środkowo-Wschodniej przypadła w udziale zwycięskiej Rosji. Próbując odpowiedzieć na postawione dość przewrotnie w tytule tego artykułu pytanie, spróbujemy zatem prześledzić poczynania armii szwedzkiej w latach 1708-1709, zwracając uwage przede wszystkim na czynniki naturalne, całkowicie obiektywne i zupełnie niezależne od ludzkiej woli, takie jak pogoda, ukształtowanie powierzchni, przeszkody naturalne itd. W moim przekonaniu to właśnie skumulowanie się naturalnych kataklizmów, przeszkód i innych, niepomyślnych w sumie okoliczności, doprowadziło do tego, że Szwedzi przystąpili do bitwy pod Połtawa znacznie osłabieni, mając niewielkie szanse na odniesienie zwycięstwa. Dodajmy również, że opracowanie to ma charakter koncepcyjny, a rekapitulacja znanych już w większości faktów służy jedynie uwypukleniu trudności, $z$ jakimi musiała się zmierzyć armia szwedzka w kampaniach 1708 i 1709 r.

Przypomnijmy zatem podstawowe fakty. Dnia 22 września 1707 r., po rocznym pobycie w Saksonii, armia szwedzka w okolicach Rawicza ponownie przekroczyła granicę Rzeczypospolitej. Nie napotkała większego oporu ze strony wojsk rosyjskich. Piotr I zabronił bowiem swoim generałom staczania większych bitew. Mieli oni natomiast w czasie odwrotu ogołocić jak największe obszary państwa polsko-litewskiego $z$ żywności i furażu, aby utrudnić zaopatrzenie armii szwedzkiej w czasie spodziewanej wyprawy Karola XII na Moskwę. Podobne instrukcje otrzymali rosyjscy dowódcy na terenach graniczących z Rosja. Tymczasem król Szwecji zamiast ruszyć w kierunku Wisły, rozłożył się obozem w Słupcy, gdzie postanowił czekać na nadejście uzupełnień $z$ kraju. Kiedy wreszcie doczekał się posiłków, miał pod swoimi rozkazami ponad 43 tys. dobrze wyekwipowanych i zaprawionych w bojach żołnierzy. Co ciekawe, szykując się do wyprawy na Moskwę, Karol XII w ogóle nie brał pod uwagę oporu ze strony konfederatów sandomierskich, którzy nie uznawali władzy wyniesionego na tron polski przez Szwedów Stanisława Leszczyńskiego. Liczył na to, że całkowicie od niego zależny król Stanisław (dysponujacy ponad 20 tys. żołnierzy), wsparty przez ośmiotysięczny korpus szwedzki generała-majora Ernsta Detlowa von Krassowa, szybko upora się $z$ armią koronną dowodzona przez hetmana Adama Mikołaja Sieniawskiego, po czym ruszy na 
pomoc jego głównym siłom walczącym przeciwko wojskom rosyjskim ${ }^{1}$. Jak się miało okazać, były to jednak błędne założenia.

Tymczasem armia rosyjska odeszła aż za Bug, rozkładając się na leże zimowe na linii ciągnącej się od Pułtuska aż po Brześć Litewski. Karol XII postanowił więc zaatakować nieprzygotowanego do walki wroga. W początkach grudnia 1707 r. podjął próbę sforsowania Wisły pod Włocławkiem. Dryfująca kra uniemożliwiła jednak zbudowanie mostu. Przez następny miesiąc król czekał więc na nadejście mrozów. Dopiero 10 stycznia 1708 r. armia szwedzka mogła rozpoczać przeprawę. Siły wyruszajace przeciwko Rosjanom składały się z 16200 piechoty, 12250 dragonów i 8450 jazdy - łącznie więc liczyły około 37 tys. żołnierzy. Władca Szwecji postanowił uderzyć na stojące nad Bugiem wojska rosyjskie $z$ boku, od strony północnego Mazowsza. Dlatego też poprowadził swoich ludzi przez Puszczę Myszyniecką. Tu jednak napotkał na zaciekły opór ze strony Kurpiów, którzy atakując $z$ ukrycia, zadali najeźdźcom poważne straty. Armia szwedzka straciła około 1000 ludzi i mnóstwo koni. Brak zwierząt pociagowych sprawił, że Szwedzi musieli spalić wieziony przez siebie most pontonowy i porzucić znaczną liczbę wozów taborowych. W Korycinie dołączył jednak do armii szwedzkiej kilkutysięczny korpus wojsk Leszczyńskiego, który nadszedł od strony Warszawy ${ }^{2}$.

Na wieść o rozpoczęciu przez Karola XII działań wojennych Piotr I opuścił Moskwę i przybył do Grodna, gdzie znajdowała się

${ }^{1}$ Por. J. Wimmer, Wojsko Rzeczypospolitej $w$ dobie wojny pótnocnej (17001717), Warszawa 1956, s. 321-323; C. Sarauw, Die Feldzüge Karl's XII: Ein quellenmässinger Beitrag zur Kriegsheschichte und Kabinetpolitik Europa's im XVIII. Jahrhundert, Leipzig 1881, s. 229-232; F.G. Bengts s on, The life of Charles XII king of Sweden 1697-1718, London 1960, s. 247-250; Z. A nu sik, Karol XII, WrocławWarszawa-Kraków 2006, s. 172-175; P. From, Klęska pod Połtawa. Kampania Karola XII $w$ Rosji $w$ latach 1707-1709, Zabrze 2010, s. 67-73.

${ }^{2}$ Por. C. Sarauw, op. cit., s. 232; F.G. Bengtsson, op. cit., s. 250-251; J. Wimmer, op. cit., s. 324-326; Z. Anusik, op. cit., s. 176-178; P. From, op. cit., s. 73-75, 78-81. W kwestii oporu chłopów kurpiowskich przeciwko przemarszowi wojsk szwedzkich przez Puszczę Myszyniecka por. E. Otwinowski, Dzieje Polski pod panowaniem Augusta II od roku 1696-1728, Kraków 1849, s. 131; W. Rakows ki, Pamiętniki, wyd. E. Piotrowski, Żytomierz 1860, s. 87; K. Zawis za, Pamiętniki, wyd. J. Bartoszewicz, Warszawa 1862, s. 257; Löjtnant Joachim Matthiae Lyths dagbok 1703-1722 [dalej: J. Lyth, op. cit.], [w:] Karolinska krigares dagböcker, del. 2, Lund 1902, s. 48; G. Adlerfelt, Leben Karls des Zwölften, König von Schweden, Frankfurt-Leipzig 1740, s. 60-70; J.A. N ord be rg, Histoire de Charles XII, Roi de Suéde, t. II, La Haye 1748, s. 204-206; W. Se rczyk, Połtawa 1709, Warszawa 1982, s. 50. 
kwatera główna jego armii w Polsce. Zamiarem cara było powstrzymanie marszu Szwedów na linii Niemna, gdzie zgromadził około 40 tys. piechoty. Król Szwecji musiał za wszelką cenę odrzucić siły nieprzyjacielskie, które uniemożliwiały swobodna komunikację między jego własną armia a stacjonującym w Kurlandii korpusem generała Adama Ludviga von Lewenhaupta. Postanowił więc bez zwłoki uderzyć na Grodno, licząc na to, że niespodziewany atak pozwoli mu pochwycić do niewoli samego cara. Dnia 27 stycznia 1709 r. niewielki oddział wojsk szwedzkich pod dowództwem Karola XII opanował Grodno. Piotr I miał sporo szczęścia, gdyż opuścił to miasto na dwie godziny przed wkroczeniem Szwedów. W połowie lutego armia szwedzka opuściła Grodno i ruszyła w stronę Mińska. Tymczasem Rosjanie przystapili do systematycznej dewastacji terenów Wielkiego Księstwa Litewskiego. W ten sposób Piotr próbował powstrzymać marsz Karola w kierunku granic własnego państwa. Wkrótce też Szwedom zaczęło brakować żywności. Największym problemem okazała się jednak sprawa furażu. Szybko stało się jasne, że wyprawę na wschód trzeba będzie odłożyć do wiosny, gdy pojawią się świeże trawy. $Z$ tego powodu Karol XII zdecydował się rozłożyć swoją armię na leżach zimowych, rozrzuconych na ogromnym obszarze od Grodna do Wilna i Mińska. Sam stanął w Smorgoniach. Na odbytej tu radzie wojennej dowódcy szwedzcy zażądali od króla marszu w kierunku Inflant, żeby odzyskać zajęte przez wojska rosyjskie tereny. Karol XII stanowczo sprzeciwił się jednak temu zamysłowi, gdyż zamierzał skierować główne uderzenie swojej armii w głąb Rosji. Po opuszczeniu Smorgoni król wyruszył do Radoszkowic i przebywał tam od 28 marca aż do 17 czerwca 1708 r. $^{3}$

Wiosną 1708 r. król Szwecji dysponował w sumie 70 tys. żołnierzy w armii polowej, mając przeciwko sobie 90 tys. Rosjan. Należy jednak zaznaczyć, że razem $z$ nieregularnymi oddziałami Kozaków i Kałmuków siły Piotra I dość znacznie przekraczały liczbę 100 tys. ludzi. Różnica nie była więc zbyt duża i Karol spokojnie czekał na początek przyszłej rozgrywki. Opracowany przez króla plan kampanii przewidywał, że w czasie, kiedy główna armia szwedzka podejmie marsz na Moskwę, starając się zmusić Piotra do stoczenia decydującej bitwy, generał Georg Lybecker uderzy z Finlan-

${ }^{3}$ Por. F.G. Bengtsson, op. cit., s. 252-255; P. From, op. cit., s. 81-87; J. Wimmer, op. cit., s. 326; Z. Anu sik, op. cit., s. 178-180; W. Serczyk, op. cit., s. $50-51$. 
dii na Ingrię, generał Adam von Lewenhaupt ruszy z Kurlandii na południe, by połączyć się z siłami głównymi, a generał Ernst von Krassow i król Stanisław Leszczyński, rozbiwszy wcześniej konfederatów sandomierskich w Polsce, skierują się na Ukrainę. Dnia 17 czerwca 1708 r. Karol XII opuścił Radoszkowice, rozpoczynając nowa kampanię. Na miejsce koncentracji armii wyznaczono Mińsk, skąd Szwedzi pomaszerowali na Borysów. Ich marsz był bardzo utrudniony ze względu na duże kompleksy leśne i bagna. Dodatkowym utrudnieniem było to, że większość armii szwedzkiej szła drogami leżącymi na południe od głównego traktu, gdyż Karol chciał oskrzydlić wroga i zmusić go do opuszczenia umocnionej pozycji. Podczas gdy maszerująca głównym traktem awangarda armii szwedzkiej zbliżała się już do Berezyny, pozostałe oddziały $z$ trudem przedzierały się przez fatalne drogi, które wkrótce, pod wpływem nieustannie padającego deszczu, przemieniły się w bezdenne bagniska. Ciężki, wyładowany po brzegi tabor pozostał z tyłu. Wiózł on bowiem zapasy żywności i wyposażenia wystarczające na trzy miesiące. Po sforsowaniu Berezyny wojska szwedzkie kontynuowały marsz w kierunku rzeki Druci przez jeszcze trudniejszy teren. Deszcz padał nadal, zmieniając ziemię w morze błota. W dniu 7 lipca 1708 r., nie napotykajacc oporu ze strony wojsk rosyjskich, Szwedzi sforsowali Druć w Aleszkowicach (Oleszkowicach) ${ }^{4}$.

Dnia 11 lipca przednie oddziały armii szwedzkiej dotarły do wsi Hołowczyn. Tu Szwedzi napotkali duże siły rosyjskie dowodzone przez Borysa Szeremietiewa i Aleksandra Mienszykowa. Postanowili oni bronić przepraw przez rzekę Wabicz, rozmieszczając swoje wojska wzdłuż jej biegu. Było to posunięcie o tyle niefortunne, że część oddziałów rosyjskich, stojących na północ od Hołowczyna, nie mogła wziąć udziału w bitwie, gdyż była oddzielona od sił głównych przez rozległe bagno. Na południe od niego rozmieszczono około 32 tys. żołnierzy carskich. Ukształtowanie terenu przemawiało na korzyść Rosjan, których od Szwedów oddzielały rzeka o bagnistych brzegach, bagno i umocnienia ziemne. Rzeka była jednak miejscami tak płytka, że można ja było sforsować wpław, a bagno przedzielało pozycje wojsk rosyjskich na dwie odosobnione

${ }^{4}$ Por. C. Sarauw, op. cit., s. 238-239; F.G. Bengts so n, op. cit., s. 270-274; P. From, op. cit., s. 129-140; J. Wimmer, op. cit., s. 326-328; Z. Anusik, op. cit., s. 183-186; A. Stille, Carl XII:s fälttågsplaner 1707-1709, Lund 1908; B. Tielpuchowski, Siewiernaja wojna 1700-1721, Moskwa 1946, s. 60-61 (tu o rosyjskich przygotowaniach do odparcia uderzenia szwedzkiego). 
części. Karol XII postanowił sforsować rzekę na wprost bagna, które oddzielało dywizję Borysa Szeremietiewa od dywizji księcia Nikity Repnina i korpusu kawalerii generała Henrika Goltza, przejść przez nie i uderzyć na tyły wojsk rosyjskich. Dnia 14 lipca wojska szwedzkie ruszyły do ataku. Pierwsze uderzenie spadło na dywizję księcia Repnina, który nie mogąc doczekać się posiłków od Szeremietiewa i Goltza, opuścił umocniony obóz i zarządził odwrót. Kiedy zaś generał Goltz wysłał na pomoc Repninowi jedna ze swoich trzech brygad dragonów, została ona zatrzymana przez wchodzace sukcesywnie do boju szwadrony kawalerii szwedzkiej, która sforsowała tymczasem bagno. Pod wpływem naporu Szwedów rosyjscy dragoni poszli w rozsypkę. Równie szybko szwedzcy jeźdźcy uporali się $z$ dwiema następnymi brygadami dragonów Goltza, którzy rzucili się do panicznej ucieczki. Mając do dyspozycji na początku bitwy 400, a pod jej koniec 2500 ludzi, feldmarszałek Karl Gustaf Rehnsköld zdołał pokonać i rozbić 10 tys. kawalerii generała Henrika Goltza. Rosyjscy dezerterzy twierdzili później, że Goltz stracił pod Hołowczynem aż 2500 zabitych, rannych i zaginionych żołnierzy. Po rejteradzie Repnina i klęsce Goltza na polu bitwy pozostała jedynie dywizja Borysa Szeremietiewa. Mimo że istniała realna szansa na jej zniszczenie, Karol XII, niepotrzebnie opóźniając szturm na rosyjski obóz, umożliwił jej odejście spod Hołowczyna. Co ciekawe, Rosjanie dość szybko sfabrykowali raport, w którym znacznie zaniżyli liczbę swoich zabitych, rannych i zaginionych w tej bitwie żołnierzy. W porzuconych obozach Repnina i Szeremietiewa Szwedzi znaleźli wiele armat oraz znaczne zapasy żywności i furażu. Źródła nie wspominają natomiast o żadnych rosyjskich jeńcach. Jest więc wielce prawdopodobne, że Karol zabronił brać Rosjan do niewoli, nie mając żadnych możliwości ich wyżywienia ${ }^{5}$.

Zwycięstwo pod Hołowczynem otworzyło armii szwedzkiej drogę w kierunku Dniepru. Licząc się $z$ możliwością sforsowania przez Szwedów tej rzeki, car wydał rozkaz spalenia wszystkich miejscowości leżących na trasie ich spodziewanego przemarszu. Tymczasem 20 lipca Karol zajął Mohylew. Ponieważ miasto nie zostało zniszczone przez Rosjan, postanowił zatrzymać się tutaj przez kilka tygodni, dając odpocząc swoim zmęczonym żołnierzom. Już w czasie marszu w stronę Hołowczyna Szwedzi zaczęli odczuwać

${ }^{5}$ Por. P. From, op. cit., s. 140-170; F.G. Bengts son, op. cit., s. 274-286; Z. Anusik, op. cit., s. 186-194; C. Sarauw, op. cit., s. 241-243; J. Wimmer, op. cit., s. 328; Tielpuchowski, op. cit., s. 62; W. Serczyk, op. cit., s. 52. 
pierwsze braki zaopatrzeniowe. W okolicach Mohylewa król musiał znaleźć jedzenie zarówno dla żołnierzy i koni, jak i dla wszystkich służb tyłowych i ogromnego taboru. W sumie miał więc do wyżywienia 45 tys. ludzi i 35 tys. koni. W Mohylewie armia szwedzka nie miała już żadnych zapasów jedzenia i paszy. Musiała więc nie tylko zaspokajać swoje bieżące potrzeby, lecz także gromadzić zaopatrzenie na druga część kampanii. I chociaż Rosjanie nie zdążyli zniszczyć okolic Mohylewa, to żywności było naprawdę mało, a ciągle padające deszcze opóźniły wegetację zbóż. Jednak to właśnie zielone, niezżęte jeszcze zboże zaspokajało w części potrzeby wygłodniałej armii. Zimno i głód sprawiły, że zaczęły się szerzyć choroby, a coraz bardziej niezadowoleni żołnierze sarkali, że mają trzech lekarzy: Czosnek, Wódkę i Śmierć. Nie mogąc kontynuować marszu na wschód, Karol XII czekał więc w Mohylewie: na żniwa, żeby uzupełnić zapasy, na wyzdrowienie rannych spod Hołowczyna, których nie zamierzał zostawiać za soba, na ustanie deszczu, który rozmył wszystkie drogi, oraz na przybycie $z$ Kurlandii korpusu generała Adama von Lewenhaupta ${ }^{6}$.

Ten ostatni otrzymał rozkaz, aby jego korpus był gotowy do wymarszu na początku letniej kampanii. Generał miał zgromadzić trzymiesięczne zapasy dla swoich żołnierzy oraz zaopatrzenie dla głównych sił armii szwedzkiej. W początkach lipca 1708 r. korpus Lewenhaupta w sile 7500 piechoty oraz 5000 kawalerii i dragonów ruszył w stronę granic Litwy. Sam generał pozostał jednak w Rydze jeszcze przez miesiąc i dołączył do swoich oddziałów dopiero 9 sierpnia, kiedy te doszły zaledwie do okolic Wilna. W ciągu miesiąca korpus Lewenhaupta przebył więc tylko $230 \mathrm{~km}$. Co prawda, w lipcu 1708 r. padały bez przerwy ulewne deszcze, które zamieniły litewskie drogi w grzaskie trzęsawiska, ale nie usprawiedliwia to bynajmniej tak powolnego marszu szwedzkich oddziałów. W sierpniu i wrześniu korpus Lewenhaupta nadal maszerował bardzo wolno, mozolnie posuwając się w stronę Berezyny Pacowskiej. Tymczasem sytuacja wojsk szwedzkich pod Mohylewem uległa znacznemu pogorszeniu. Cała okolica została bowiem ogołocona $z$ żywności. Zaczęło też brakować świeżej trawy na pastwiskach. $\mathrm{Na}$ domiar złego plony okazały się wyjatkowo słabe i nie udało się zgromadzić zapasów żywności na sześć tygodni. Dlatego też

${ }^{6}$ Por.Z. Anusik, op. cit., s. 194-196; P. From, op. cit., s. 191-197; F.G. Bengtss o n, op. cit., s. 287-289; C. Sarauw, op. cit., s. 244; J. Wi m m er, op. cit., s. 329; W. Serczyk, op. cit., s. 52-53. 
król nie mógł dłużej czekać na Lewenhaupta. W dniu 16 sierpnia zwinał obóz, przeszedł Dniepr i bardzo wolno ruszył na południowy wschód. W czasie tego powolnego marszu szwedzcy żołnierze ścinali, młócili i mełli na mąkę zboże na mijanych polach. Dnia 1 września armia szwedzka dotarła do Czerykowa. Tu król nakazał postój, oczekując na wieści od Lewenhaupta. Wysłał też do niego rozkaz, aby jak najszybciej połączył się $z$ jego armią. List ten dotarł do generała 9 września w Dołhinowie, oddalonym o około $270 \mathrm{~km}$ w linii prostej od miejsca pobytu króla. Nie wiedząc nic o losach korpusu Lewenhaupta, Karol XII opuścił Czeryków i ruszył na północ, w stronę Smoleńska?.

Dnia 8 września 1708 r. armia szwedzka dotarła do Malatycz, niedaleko Mścislawia, gdzie zatrzymała się na krótki postój. Następnego dnia obozujący tu Szwedzi dali się zaskoczyć Rosjanom. W krwawym boju stracili 3000 żołnierzy. Nie byli też w stanie przeszkodzić wrogowi w paleniu okolicznych wsi i niszczeniu furażu. W dniu 22 września Karol XII stoczył z Rosjanami ciężki bój pod Tatarskiem. Co prawda, udało mu się odrzucić i zmusić do odwrotu siły rosyjskie, ale sukces ten został okupiony dużymi stratami. Tatarsk, położony niedaleko Orszy, okazał się najbardziej na północ wysuniętym punktem, do którego udało się dojść Szwedom. Cały horyzont na północ i wschód od tej miejscowości zasnuty był dymami. Rosjanie niszczyli bowiem wszystkie miejscowości leżące na trasie spodziewanego marszu Karola XII. Wycinali też lasy i tarasowali drogi powalonymi drzewami. Żołnierzom szwedzkim znowu zaczęło brakować żywności. Gdyby król pozostał tu dłużej, jego ludzi czekałaby śmierć głodowa. Marsz na Smoleńsk przez tereny spustoszone przez Rosjan również nie wchodził w rachubę. Otrzymawszy fałszywą wiadomość, że korpus Lewenhaupta dotarł już do Dniepru, król Szwecji podjął decyzję o marszu na Ukrainę Siewierską. Przodem wysłał liczaca 3000 ludzi straż przednia z zadaniem opanowania wszystkich brodów i mostów na drogach wiodących w tamtym kierunku. Dnia 26 września główne siły szwedzkie ruszyły na południe. Karol nie zrezygnował bynajmniej $z$ dotarcia do Moskwy. Do stolicy carów chciał jednak dojść inna drogą. Szed1 teraz bowiem w stronę innego szlaku do Moskwy wiodacego przez Briańsk i Kaługę, szlaku, który przecinał również Ukrainę Siewier-

7 Por. F.G. Bengts son, op. cit., s. 289-295; Z. Anusik, op. cit., s. 196-199; P. From, op. cit., s. 95-106; J. Wimmer, op. cit., s. 329; B. Tielpuchowski, op. cit., s. 63; W. Serczyk, op. cit., s. 53. 
ska. Silny opór wojsk rosyjskich na drodze smoleńskiej oraz splot innych okoliczności zmusiły więc Karola, po raz pierwszy w tej wojnie, do zmiany planów strategicznych. W kampanii 1708 r. spotkał króla Szwecji szereg zawodów. Zawiódł go Lewenhaupt, zawiodło go rozpoznanie, ale przede wszystkim zawiodła go pogoda. Obfite deszcze padające latem 1708 r. spowodowały opóźnienie marszu korpusu Lewenhaupta i wpłynęły w decydującym stopniu na niskie plony zbóż na Litwie i Białorusi. Chroniczny brak żywności w obozie szwedzkim zmusił $z$ kolei Karola najpierw do opuszczenia Mohylewa, a później do wycofania się spod Tatarska ${ }^{8}$.

Szwedzka straż przednia, dowodzona przez generała Andersa Lagercronę, otrzymała zadanie opanowanie ważnego punktu strategicznego, jakim było miasto Poczep. Lagercrona wszedł do wielkich lasów ciągnacych się między rzekami Soż a Put, a w ślad za nim podażyła cała armia. Droga była fatalna, codziennie trzeba było usuwać $z$ niej zwalone drzewa i inne przeszkody, a do tego brakowało zarówno żywności, jak i furażu. Na dodatek wśród głodnych i wyczerpanych ludzi wybuchła epidemia dyzenterii. Ten ciężki marsz przez lasy kosztował Szwedów mnóstwo wysiłku. Pociąnną też za sobą ogromne straty w ludziach. Tymczasem Poczep, do którego zmierzali Szwedzi, został opanowany przez Rosjan. Okazało się bowiem, że Lagercrona zmylił drogę i zamiast do Poczepu dotarł do Staroduba, położonego około $70 \mathrm{~km}$ na południe od tego miasta. $\mathrm{Na}$ domiar złego, w czasie, kiedy armia Karola XII pogrążała się w leśnych ostępach między Sożą a Putem, korpus Lewenhaupta nie dotarł nawet do Dniepru. Od głównej armii oddzielały go więc teraz dwie duże rzeki: Dniepr i Soż. Wkrótce król otrzymał wiadomość, że w lukę między jego armia a korpusem Lewenhaupta weszły duże siły rosyjskie. Nad generałem i jego żołnierzami zawisło śmiertelne niebezpieczeństwo. Znajdujacy się w środku ogromnych lasów nad Sożą Karol nie mógł jednak nic zrobić. Do tej pory myślał, że czekał na Lewenhaupta zbyt długo. Teraz uświadomił sobie, że czekał zbyt krótko. Równie fatalne wieści nadeszły od Lagercrony, który zamiast zająć Starodub, pozwolił na jego opanowanie przez Rosjan. Nie zrobił też niczego, aby przeszkodzić wojskom carskim w zniszczeniu całej północnej części Siewierszczyzny. Kiedy więc regimenty

8 Por. P. From, op. cit., s. 199-206; Z. Anusik, op. cit., s. 200-205; F.G. Bengtsson, op. cit., s. 295-301; J. Wimmer, op. cit., s. 329; W. Serczyk, op. cit., s. 53-54; W. Ko no p czyńs ki, Polska a Szwecja. Od pokoju oliwskiego do upadku Rzeczypospolitej 1660-1795, Warszawa 1924, s. 57. 
Karola XII przybyły wreszcie na Ukrainę Siewierska, ich sytuacja w zakresie zaopatrzenia wcale znaczaco się nie poprawiła ${ }^{9}$.

Jak by tych wszystkich nieszczęść było mało, w kwaterze głównej króla Szwecji pojawił się młody żołnierz z korpusu Lewenhaupta, który przyniósł wiadomość, że 8 października 1708 r. generał stoczył z Rosjanami zaciętą bitwę pod wsią Leśna, niedaleko Propojska. Jaki był rezultat bitwy, żołnierz nie mógł jednak powiedzieć, gdyż stracił kontakt ze swoim oddziałem i przez resztę nocy samotnie błąkał się po lesie. Spodziewając się najgorszego, Karol musiał podjąć decyzję o kierunku dalszego marszu. W istocie jednak nie miał żadnego wyboru. Uciekając przed głodem, mógł pójść tylko na południe - tam, gdzie spodziewał się znaleźć żywność dla swoich wygłodzonych żołnierzy i paszę dla swoich wychudzonych koni. Jedynym wyjściem było więc podjęcie marszu w stronę Zadnieprza. Król liczył na to, że będzie tam wystarczająca ilość prowiantu dla jego armii. Mógł się też spodziewać, że wiosną 1709 r. pojawią się na Ukrainie oddziały Stanisława Leszczyńskiego i regimenty Ernsta von Krassowa. Największe nadzieje wiązał jednak $z$ osobą hetmana nakaźnego Ukrainy Lewobrzeżnej, Iwana Mazepy. Dotychczasowy wierny sługa cara zawarł bowiem tajne porozumienie ze Szwedami. W myśl tej umowy armia szwedzka miała przezimować na Ukrainie Siewierskiej, a hetman miał w tym czasie przeprowadzić koncentrację oddziałów kozackich $z$ Lewo- i Prawobrzeżnej Ukrainy oraz nakłonić do wystapienia przeciwko carowi Kozaków Dońskich, Tatarów Białogrodzkich, a nawet Kałmuków. Decyzja Karola o marszu na Zadnieprze była więc $w$ istocie złamaniem porozumienia $z$ Mazepa, który chciał do końca oczekiwać na wynik starcia armii rosyjskiej ze szwedzką i dopiero wówczas zadeklarować się po stronie zwycięzcy. Karol XII nie znał rzecz jasna planów hetmana, ale wiedział, że pojawienie się na Zadnieprzu wojsk szwedzkich zmusi go do opowiedzenia się po jego stronie. Poza tym dalszy pobyt na spustoszonej przez Rosjan Siewierszczyźnie nie miał najmniejszego sensu. Dlatego też 22 października 1708 r. Szwedzi zwinęli obóz pod Kosteniczami i ruszyli w stronę Staroduba. Nie uszli jednak daleko. Już w Truchanowie natknęli się bowiem na resztki rozbitego pod Leśna korpusu Adama von Lewenhaupta ${ }^{10}$.

9 Por. F.G. Bengtss on, op. cit., s. 302-306; Z. Anusik, op. cit., s. 206-210; P. From, op. cit., s. 206-212; J. Lyth, op. cit., s. 60-61.

${ }^{10}$ Por. Z. Anusik, op. cit., s. 210-212; F.G. Bengtsson, op. cit., s. 306-310; J. Wimmer, op. cit., s. 326, 329-330; W. Serczyk, op. cit., s. 60-100 (tu szcze- 
Ten ostatni 4 października przeprawił się wreszcie przez Dniepr i ruszył na spotkanie $z$ główną armią szwedzką. Dnia 8 października otrzymał jednak wiadomość, że jego tylna straż została zaatakowana przez wojska rosyjskie. W tej sytuacji Lewenhaupt podją fatalna w skutkach decyzję o stoczeniu otwartej bitwy $z$ wrogiem. Przez cały dzień Szwedzi stali w miejscu, czekajac na nadejście Rosjan. Późnym popołudniem generał cofnął nieco swoich ludzi, ale potem znowu ustawił ich w szyku bojowym. Szwedzcy żołnierze stali tak cała noc. Następnego dnia korpus Lewenhaupta dotarł do wsi Leśna, położonej w odległości około $15 \mathrm{~km}$ na północ od Propojska, gdzie generał zamierzał sforsować Soż i odgrodzić się rzeka od ścigajacych go Rosjan. Przed przystapieniem do przeprawy Lewenhaupt zarządził jednak przegląd taboru. Zamierzał bowiem porzucić część zbędnych wozów. W trakcie tej niepotrzebnej i mocno spóźnionej czynności pojawiły się pod Leśną oddziały rosyjskie. Mimo zażartych ataków wojsk carskich, Szwedzi zdołali w zasadzie utrzymać zajmowane pozycje. Wieczorem wrogie wojska rozłożyły się na nocleg. Dowiedziawszy się, że Rosjanie oczekuja na nadejście posiłków, Lewenhaupt zarządził odwrót do Propojska. W czasie nocnego marszu, który odbywał się w strugach padającego deszczu, nastapił jednak całkowity rozkład szwedzkiego korpusu. Wśród żołnierzy wybuchła panika. Jedni rzucili się do plądrowania własnego taboru, inni rozpierzchli się we wszystkich kierunkach. Korpus Lewenhaupta przestał w zasadzie istnieć. Generał stracił prawie 7000 żołnierzy. W Propojsku rozkazał zaś spalić cały tabor wraz z zaopatrzeniem dla armii królewskiej na sześć tygodni. Być może jednak nie udało mu się zniszczyć wszystkiego, gdyż Rosjanie twierdzili później, że po bitwie pod Leśną zdobyli ogromne zapasy żywności i materiałów wojennych. Następnie $z$ resztą swoich żołnierzy Lewenhaupt ruszył w dół Soży, przeprawił się przez rzekę w miejscowości Glinka i po ciężkim marszu nieopodal Truchanowa natknał się na wysunięte oddziały głównej armii szwedzkiej. Miał ze soba 6000 wyczerpanych marszem i głodnych ludzi. Nie tylko nie dostarczył królowi tak potrzebnego mu zaopatrzenia, ale

gółowo o kulisach przejścia Iwana Mazepy na stronę Szwedów). Por. też On the Eve of Poltava: The letters of Ivan Mazepa to Adam Sieniawski, 1704-1708, ed. O. Subtelny, New York 1975; oraz Z. A nu si k, Fenomen Iwana Mazepy $w$ historiografii polskiej XIX i XX w., [w:] Mity i stereotypy $w$ dziejach Polski $i$ Ukrainy $w X I X$ i XX wieku, red. A. Czyżewski, R. Stobiecki, T. Toborek, L. Zaszkilniak, Warszawa-Łódź 2012, s. 224-248 (tu także obszerna bibliografia); W. Konopczyńs ki, op. cit., s. 57. 
jeszcze obarczył go obowiązkiem wyżywienia dodatkowych kilku tysięcy żołnierzy. Niemniej jednak połączenie się sił królewskich $z$ resztkami korpusu Lewenhaupta podniosło ogólna liczebność armii szwedzkiej do niemal 32 tys. ludzi. Teoretycznie była to nadal dość znaczna siła. W rzeczywistości żołnierze byli bardzo osłabieni przez głód i dyzenterię. Na domiar złego Szwedom zaczęło brakować nie tylko żywności, lecz także prochu i innych materiałów wojennych $^{11}$.

Kolejny zawód spotkał Karola XII ze strony Iwana Mazepy. Ten bowiem, zamiast spokojnie czekać w Baturynie na nadejście Szwedów, na wieść o zbliżaniu się armii rosyjskiej porzucił miasto, przeprawił się przez Desnę i z 4000 mołojców przybył do obozu króla Szwecji. Zapewnienia hetmana, że porwie do walki przeciwko Rosji 30 tys. Kozaków, okazały się obietnicami bez pokrycia. Dnia 14 listopada wojska szwedzkie, mimo zaciętego oporu Rosjan, sforsowały Desnę. Karol XII miał teraz otwartą drogę do Baturyna, gdzie spodziewał się znaleźć prowiant i kwatery dla swojej zmęczonej i wygłodzonej armii. Jednak tego samego dnia, kiedy Szwedzi stanęli na południowym brzegu Desny, Aleksandr Mienszykow zdobył i spalił Baturyn. Wojska rosyjskie zniszczyły też zgromadzone tam zapasy żywności i materiałów wojennych. Dnia 29 listopada Szwedzi stanęli w Romnach. Ponieważ wcześniej Mazepa zgromadził tu ogromne zapasy żywności i furażu, szwedzcy żołnierze mogli wreszcie odpocząć i najeść się do syta. Karol XII postanowił spędzić w Romnach kilka najbliższych tygodni. W czasie, kiedy król przemierzał bezdroża Lewobrzeża, jego generałowie doznali kolejnych niepowodzeń w Ingrii oraz w Polsce. Generał Georg Lybecker po nieudanym oblężeniu Petersburga wycofał się do Finlandii. Równie źle działo się w Polsce. Konfederaci sandomierscy kontrolowali bowiem Małopolskę, Wołyń i Podole, odgradzając Leszczyńskiego i Krassowa od Ukrainy. Dopiero w początkach listopada 1708 r. król Stanisław wraz ze szwedzkim korpusem posiłkowym ruszył na Podlasie, a do Małopolski wysłał dywizje Adama Śmigielskiego i Józefa Potockiego. Dnia 21 listopada 1708 r. ponieśli oni jed-

${ }^{11}$ Por. C. Hallendorff, Karl XII och Lewenhaupt år 1708, Uppsala 1902 (tu szczegółowe omówienie poczynań Lewenhaupta od wymarszu jego korpusu z Rygi do katastrofy pod Leśna); P. From, op. cit., s. 107-124, 191-247; Fänrik Robert Petrés dagbok 1702-1709, [w:] Karolinska krigares dagböcker, del. 1, Lund 1901, s. 158-183; F.G. Bengts son, op. cit., s. 310-312; Z. Anusik, Karol..., s. 212215; J. Lyth, op. cit., s. 61-62; J. Wimmer, op. cit., s. 330; W. Se rczyk, op. cit., s. $55-57$. 
nak ciężką klęskę w bitwie pod Koniecpolem. Obie dywizje zostały zniszczone, a konfederaci sandomierscy opanowali województwa sieradzkie i łęczyckie. Część sił Leszczyńskiego stojąca w Wielkopolsce została odcięta od jego głównej armii na Podlasiu. W tej sytuacji król Stanisław i generał Krassow zrezygnowali $z$ pomysłu podjęcia marszu na Ukrainę. Zamiast tego w końcu stycznia 1709 r. postanowili przebić się $z$ powrotem do Wielkopolski. Karol XII nie mógł więc na razie liczyć na żadne posiłki z Polski ${ }^{12}$.

W grudniu 1708 r. armia szwedzka rozłożyła się na leże zimowe między Romnami, Hadziaczem, Łochwica a Przyłukami. Z trzech stron otaczali ja Rosjanie, a Piotr I postanowił nękać Szwedów nawet w zimie. Często też dochodziło do utarczek kawalerii. Na wieść o tym, że wojska carskie zamierzają zaatakować Hadziacz, Karol XII opuścił Romny i ruszył na pomoc stacjonujacym tam oddziałom. Nie zdążył jednak zapobiec zniszczeniu przez Rosjan znajdujących się w pobliżu Hadziacza wielkich magazynów prowiantowych. Rosyjska kawaleria zajęła też pozbawione załogi wojskowej Romny, gdzie również zniszczono duże zapasy żywności i furażu. Tymczasem w całej Europie nastąpił atak straszliwej zimy. Na Zadnieprzu silne mrozy przyszły w nocy z 29 na 30 grudnia 1708 r. Mróz był tak wielki, że wielu żołnierzy szwedzkich zamarzło w Hadziaczu na śmierć. $Z$ powodu mrozu nie odbyły się nawet msze święte $\mathrm{w}$ pierwszy i drugi dzień świąt Bożego Narodzenia, co w armii szwedzkiej było wydarzeniem zupełnie wyjątkowym. Już 10 stycznia 1709 r. Karol wyprowadził jednak swoich żołnierzy w pole. Lekkomyślne opuszczenie Hadziacza kosztowało życie kolejnych kilkuset jego ludzi. Dnia 17 stycznia 1709 r. wojska szwedzkie przypuściły szturm na niewielka fortecę Wepryk. Atak został jednak krwawo odparty przez rosyjską załogę. Wkrótce potem rosyjski garnizon złożył broń, a Karol został obarczony 1500 jeńcami, których musiał żywić i pilnować. Zdobycie tej niewielkiej twierdzy, której zajęcie nie było wcale koniecznościa, kosztowało go stratę ponad 1000 oficerów i żołnierzy. Pod Weprykiem król Szwecji po raz pierwszy zawiódł jako dowódca. Posłał na śmierć ludzi, których $z$ lepszym skutkiem mógłby wykorzystać w następnych

12 Por. F.G. Bengts son, op. cit., s. 313-318; Z. Anu sik, Karol..., s. 217-220; J. Wimmer, op. cit., s. 330-336; C. Sarauw, op. cit., s. 257; K. Zawisza, op. cit., s. 261; W. Rakowski, op. cit., s. 88, 100, 115; E. O twinowski, op. cit., s. 132-137, 139; W. Serczyk, op. cit., s. 57-58; P. From, op. cit., s. 171-190; F. Hj elm qui st, Kriget i Finland och Ingermanland 1707 och 1708, Lund 1909. 
operacjach. Po zajęciu Wepryka Szwedzi ruszyli w stronę Charkowa, skąd król zamierzał skręcić na szlak wiodący przez Kursk, Orzeł i Tułę do Moskwy. Dnia 8 lutego 1709 r. Karol XII pobił pod Oposzną duże zgrupowanie rosyjskiej kawalerii dowodzonej przez Aleksandra Mienszykowa. Wkrótce, 20 lutego ponownie zwyciężył Rosjan w bitwie pod Krasnokutskiem i Horodyszczem. Piotr I obawiał się uderzenia Szwedów na Woroneż. Tymczasem Karol z Horodyszcza ruszył prosto na Charków. Dnia 24 lutego armia szwedzka doszła do miasteczka Kołomak nad mała rzeka o tej samej nazwie. Tu jednak jej pochód został zatrzymany. Szwedzi nigdy nie posunęli się już dalej. Po raz kolejny wszystkie plany i zamiary Karola XII pokrzyżowała pogoda. W połowie lutego nastała bowiem niespodziewana odwilż. $Z$ nieba spadły obfite deszcze, które spowodowały topnienie śniegów. Rzeki wystapiły $z$ brzegów, a drogi zamieniły się w trzęsawiska, w których grzęzły i tonęły wozy taborowe. Wszelkie szanse na marsz w kierunku Charkowa rozpłynęły się wraz $z$ topniejącym śniegiem ${ }^{13}$.

W marcu 1709 r. król stanął w Budyszczach, gdzie ustanowił swoja kwaterę główna. Swoje oddziały rozlokował na kwaterach między Worsklą a Psiołem. Dokonał też osobistej inspekcji regimentów. Jego armia na Zadnieprzu liczyła 24-25 tys. żołnierzy i nic nie wskazywało na to, aby w najbliższym czasie udało się zwiększyć jej liczebność. Ludziom nie brakowało jedzenia, gdyż służbom kwatermistrzowskim udało się zgromadzić dość znaczne zapasy prowiantu. Wciąż brakowało jednak prochu. Poważny problem stanowiło też umundurowanie. Jeszcze gorzej wyglądała sprawa żołnierskich butów, które bardzo ucierpiały w czasie ciężkich przemarszów po fatalnych drogach Polski, Białorusi, Rosji i Ukrainy. Inspekcja armii przekonała Karola, że $z$ takimi siłami nie ma nawet co marzyć o zajęciu Moskwy. Jego doradcy nalegali na powrót do Polski, ale król postanowił pozostać na Zadnieprzu. Po tym, jak w marcu 1709 r. Kozacy Zaporoscy postanowili przejść na stronę Szwecji, liczył na to, że uda mu się zmontować szerokie przymierze przeciwko carowi $z$ udziałem Polaków, Turków i Tatarów. Na razie jednak Karol XII postanowił rozpocząć oblężenie Połtawy, jedynej twierdzy nad Worskla, w której stał silny garnizon rosyjski. W rzeczywistości jednak zdobycie tej twierdzy nie było głównym celem

13 Por. Z. Anusik, Karol..., s. 220-226; P. From, op. cit., s. 253-268; F.G. Bengts s o n, op. cit., s. 318-328; W. Serczyk, op. cit., s. 102-104, 107-109, 114-115; W. Konopczyński, op. cit., s. 57-58. 
jego działań. Król chciał prowadzić oblężenie w taki sposób, aby nie przyniosło ono zbyt szybkich efektów. Pragnał, żeby Rosjanie odnieśli wrażenie, że mimo ogromnych wysiłków nie jest w stanie zdobyć tej fortecy. Zakładał przy tym, że przekonanie o słabości Szwedów skłoni cara do przybycia $z$ odsieczą dla oblężonej twierdzy. Wówczas miałby armię rosyjską w zasięgu ręki i mógłby zmusić Piotra do stoczenia decydującej bitwy. Dnia 12 maja 1709 r. armia szwedzka opasała Połtawę ciasnym pierścieniem i przystąpiła do oblężenia. Karol robił jednak wszystko, aby odpowiedzialny za stronę techniczna tej operacji generalny kwatermistrz armii Axel Gyllenkrook nie zdobył przypadkiem miasta i nie zniweczył jego misternej pułapki. Tymczasem do obozu szwedzkiego docierały kolejne niepomyślne wiadomości. W dniu 25 maja wojska rosyjskie zdobyły bowiem i zniszczyły Sicz Zaporoska. Wieści z Polski również nie były dobre. Co prawda, w marcu 1709 r. Leszczyński i Krassow ruszyli spod Poznania w kierunku Małopolski i dotarli do Lwowa. Dowiedziawszy się jednak o marszu wysłanych na pomoc konfederatom sandomierskim wojsk rosyjskich, zrezygnowali $z$ próby przebijania się na Ukrainę. Po porażce zaś wiernych Stanisławowi Litwinów w bitwie $z$ Rosjanami pod Nakwasza na Wołyniu (23 maja) rozpoczęli odwrót na zachód. W ten sposób ostatnia próba przyjścia $z$ pomoca Karolowi XII została zniweczona przez konfederatów sandomierskich i Rosjan ${ }^{14}$.

W pewnym momencie Karol XII zdał sobie sprawę $z$ tego, że nikt i nic nie przyjdzie mu $z$ pomocą. Konsekwentnie dążył jednak do stoczenia jednej, decydującej bitwy. W początkach czerwca 1709 r. Rosjanie skoncentrowali już bardzo znaczne siły na lewym brzegu Worskli naprzeciwko Połtawy. Król Szwecji starał się ich zachęcić do przejścia rzeki. W tym celu $z$ premedytacją osłabił swoje siły na północ od fortecy. Jednak dopiero po przybyciu do obozu cara działania wojsk rosyjskich stały się bardziej energiczne. Dnia 28 czerwca Rosjanie przystąpili do forsowania Worskli

14 Por. F.G. Bengts s o n, op. cit., s. 328-339; Z. Anusik, Karol..., s. 227-234; P. From, op. cit., s. 272-286 (autor ten, opierajac się na niewtajemniczonych w plany króla relacjach A. Gyllenkrooka i A.L. v. Lewnhaupta, wyraża przekonanie, że Karol XII rzeczywiście dążył do zdobycia Połtawy. Nie wspomina również ani słowem o tym, że celem króla było ściagnięcie pod Połtawę głównej armii rosyjskiej i stoczenie jednej, decydującej o losach kampanii bitwy); B. Tielpuchowski, op. cit., s. 103-106; J. Wimmer, op. cit., s. 338-339; W. Rakowski, op. cit., s. 119, 122; E. Otwinowski, op. cit., s. 143, 148; K. Zawisza, op. cit., s. 266; W. Serczyk, op. cit., s. 105-106. 
na północ i na południe od Połtawy. Nie próbując nawet walczyć $z$ oddziałami carskimi na północy, Karol skoncentrował swoje wysiłki na powstrzymaniu próby desantu na południe od swojego obozu. W chwili, kiedy $z$ brzegu rzeki przypatrywał się walce, został postrzelony w stopę. Rana ta okazała się bardzo groźna. Po ostrej zimie przyszła bowiem goraca wiosna i upalne lato. Upały były tak wielkie, że prowadziły do osłabienia i bezsenności nawet u zdrowych żołnierzy. Chorzy i ranni umierali w tym czasie nie tylko $z$ braku opieki medycznej i lekarstw, lecz także $z$ powodu upałów, które utrudniały gojenie ran i powodowały ich ropienie. Zaropiałe rany wiązały się najczęściej $z$ wysoka gorączka, zakażeniem krwi, gangrena, a w rezultacie - ze śmiercią. Po kilku dniach w ranie króla pojawiło się zakażenie. Karol miał bardzo wysoka goraczkę, a zapalenie sięgało od stopy aż do kolana. Tymczasem 1 i 2 lipca, kiedy nieprzytomny monarcha leżał trawiony wysoka goraczką, Rosjanie rozpoczęli przerzucanie swoich głównych sił na prawy brzeg rzeki. Misterna gra, która prowadził Karol, zdawała się dobiegać końca. Tyle tylko, że ciężko ranny król nie był już w stanie wykorzystać okazji do rozstrzygnięcia losów całej wojny w jednej bitwie, do której tak konsekwentnie dążył ${ }^{15}$.

Armia szwedzka pod Połtawą składała się z 18 batalionów piechoty i 101 szwadronów jazdy, nie licząc dwóch niepełnych regimentów zatrudnionych przy pracach oblężniczych i kilku wydzielonych oddziałów kawalerii. W sumie było to nieco ponad 22 tys. Szwedów i kilka tysięcy Kozaków Zaporoskich. Żołnierze byli w dobrej kondycji. Niemniej jednak było ich niezbyt wielu w porównaniu do 43 tys. Rosjan, którzy wznieśli swój umocniony obóz pod wsią Jakowce. Przed front umocnień od strony obozu szwedzkiego wysunęli sześć redut zbudowanych w jednej linii, a prostopadle do nich wznieśli jeszcze cztery reduty, tak że w sumie system rosyjskich umocnień od tej strony przybrał kształt dużej litery T. Szykując się do generalnej batalii, czujący się nieco lepiej Karol naszkicował w ogólnych zarysach plan bitwy. Polegał on na tym, aby wziąć Rosjan przez zaskoczenie. W nocy cała armia szwedzka miała opuścić swój obóz i ruszyć w kierunku północnym, żeby do świtu zająć

15 Por. Z. Anusik, Karol..., s. 234-238; F.G. Bengts son, op. cit., s. 337-340; P. From, op. cit., s. 287-289; J. Wimmer, op. cit., s. 340; W. Serczyk, op. cit., s. 116-126 (tu powszechne w historiografii rosyjskiej stwierdzenie, że Karol XII za wszelka cenę chciał zdobyć Połtawę, a nieustanne szturmy na twierdzę kosztowały życie 6000 żołnierzy szwedzkich). 
pozycje na północ i północny zachód od rosyjskiego obozu. Szwedzi mieli wejść w lukę między obóz cara pod Jakowcami a mostami pod Petrowką. Gdyby się to udało, rankiem Rosjanie mieliby przed sobą całą armię szwedzka, a $z$ tyłu urwisty brzeg Worskli. Nawet gdyby car nie chciał stoczyć otwartej bitwy, Szwedzi mogliby zablokować go w obozie i głodem zmusić do kapitulacji. Cały problem polegał jednak na tym, że plan ten znany był jedynie najściślejszemu dowództwu armii. O jego założeniach wiedzieli Karol XII, feldmarszałek Rehnsköld i pułkownik Gustaf Henrik Siegroth, który pełnił w dniu bitwy funkcję szefa sztabu. Nie znali ich natomiast ani generał Adam von Lewenhaupt, ani generalny kwatermistrz Axel Gyllenkrook, ani też żaden $z$ dowódców pułków. Wobec niedyspozycji króla dowództwo w bitwie sprawować miał feldmarszałek Rehnsköld, a jego zastępca miał być generał piechoty Adam Lewenhaupt. Sam Karol miał towarzyszyć swoim żołnierzom, leżąc $\mathrm{w}$ specjalnie $\mathrm{w}$ tym celu skonstruowanej lektyce ${ }^{16}$.

Z punktu widzenia Szwedów bitwa pod Połtawą była jedna wielką katastrofą. Piechotę uszykowano w cztery kolumny marszowe, za którymi miała postępować uszykowana w sześć kolumn kawaleria. Niemal od razu wybuchło zamieszanie, gdyż wszystkie bataliony ruszyły $\mathrm{w}$ tym samym czasie i zaczęły wpadać na siebie, mieszając się w czasie marszu. Nie udało się też zaskoczyć obrońców redut, którzy silnym ogniem razili zgrupowanie wojsk szwedzkich. Najgorsze było jednak to, że w czasie forsowania linii rosyjskich redut $6 \mathrm{z} 18$ batalionów piechoty (uformowanej ostatecznie w trzy zmieszane kolumny) uwikłało się w zupełnie bezsensowną walkę, usiłując za wszelką cenę zdobyć jedną $z$ nich. Zaraz na początku szturmu zginął też pułkownik Siegroth, który nie zdążył przekazać dowodzącemu tym zgrupowaniem piechoty generałowi Karlowi Gustafowi Roosowi informacji, że atak na redutę przypuszczono tylko dlatego, żeby ułatwić jej ominięcie pozostałym oddziałom, a jego właściwym zadaniem jest sforsowanie linii redut, a nie ich zdobywanie. Tymczasem szwedzka kawaleria, która od zachodu obeszła linię wysuniętych umocnień rosyjskich,

16 Por. F.G. Bengts s o n, op. cit., s. 341-351; Z. Anusik, Karol..., s. 243-247; C. Sarauw, op. cit., s. 266 (tu jednak znacznie zawyżona liczba żołnierzy rosyjskich - 57 tys.); B. Ti el pu chow s ki, op. cit., s. 116 (tu zawyżona liczba żołnierzy szwedzkich - 30 tys.); J. Wim mer, op. cit., s. 340; P. From, op. cit., s. 300-302 (autor ten wspomina jedynie o naradzie króla $z$ Rehnsköldem i Siegrothem. Nie pisze natomiast nic o przygotowanym przez Karola XII planie batalii). 
odrzuciła uszykowaną za redutami jazdę Aleksandra Mienszykowa na północ i północny zachód od głównego obozu Piotra I. W ten sposób szwedzcy kawalerzyści osiagnęli planowane przed bitwą pozycje wyjściowe. Wkrótce pojawiło się również 6 batalionów piechoty, które ominęły rosyjskie reduty z lewej strony. Odnalazła się także kolumna prowadzona przez generała Adama von Lewenhaupta, która obeszła linię rosyjskich umocnień z prawej strony. Wszystkie te oddziały zajęły pozycję usytuowaną nieco na północ od rosyjskiego obozu. Feldmarszałek Rehnsköld miał jednak do dyspozycji tylko 12 zamiast 18 batalionów piechoty. Ludzie Roosa nadal bowiem szturmowali broniąca się zaciekle redutę. Kiedy zaś wreszcie nieszczęsny generał skonstatował, że jego wykrwawione oddziały nie zdobęda pozycji wroga, poprowadził swoich ludzi na wschód, do lasku jakowickiego. Tu, otoczony przez przeważające siły rosyjskie, straciwszy w zaciętej walce ogromną większość żołnierzy, poddał się wraz z 400 ludźmi, którzy przeżyli tę krwawą łaźnię. W tym samym czasie, kiedy Rosjanie zabierali do swojego obozu pierwsza grupę szwedzkich jeńców z ugrupowania Roosa, rozpoczęła się zasadnicza faza bitwy pod Połtawa ${ }^{17}$.

Tymczasem główne siły armii szwedzkiej posuwały się na północ przez bagnisty i zalesiony teren, coraz bardziej oddalając się od linii redut. Feldmarszałek Rehnsköld, coraz bardziej zaniepokojony, wysłał na poszukiwanie zaginionej kolumny generała Roosa dwa bataliony piechoty i część kawalerii. Po przejściu dwóch bagien szwedzka armia uformowała się wreszcie w szyku bojowym na północny zachód od rosyjskiego obozu. Rehnsköld miał już jednak tylko 10 batalionów piechoty, która na dodatek poniosła znaczne straty w czasie forsowania linii rosyjskich redut, oraz zaledwie cztery działa (bo tylko tyle zabrano $z$ obozu). Tymczasem Piotr I wyprowadził $z$ obozu niemal wszystkie swoje siły i ustawił je w dwóch liniach. W centrum stanęły 42 bataliony piechoty, na prawym skrzydle 17 pułków dragonii, a na lewym 6 pułków kawalerii. Rosjanie mieli też 70 armat. Widząc wroga szykującego się do bitwy, Rehnsköld postanowił niespodziewanie wstrzymać marsz na północ, uformować kolumnę marszową i wrócić na południe, wzdłuż frontu armii rosyjskiej, żeby ratować ludzi generała Roosa.

17 Por. Z. Anusik, Karol..., s. 247-255; F.G. Bengts s on, op. cit., s. 351-359; P. From, op. cit., s. 303-338; W. Serczyk, op. cit., s. 127-129 (tu jednak szereg trudnych do zaakceptowania stwierdzeń na temat poczynań armii szwedzkiej w pierwszej, wstępnej fazie bitwy). 
Szwedzi rozpoczęli więc odwrót przez „małe bagno” w kierunku innego bagna, leżącego niedaleko wsi Budyszcze. Piechota szła najbliżej frontu armii rosyjskiej, podczas gdy kawaleria, podzielona na dwie części, które w razie potrzeby uformowania szyku bitewnego miały utworzyć lewe i prawe skrzydło, posuwała się przez podmokły, trudny teren, równolegle do własnej piechoty. Około 10 rano Szwedzi znaleźli się dokładnie na wprost rosyjskich pozycji. Armia carska ruszyła do przodu, co zmusiło feldmarszałka do uformowania szyku bojowego. Swoich 10 batalionów ustawił w jednej linii po to, aby rozciagnać front jak najszerzej. Mimo to front rosyjskiej piechoty sięgał zdecydowanie dalej z każdej strony. Nie było jednak na to żadnej rady. Szwedzkich piechurów było bowiem tylko około 4000, podczas gdy Rosjan przynajmniej cztery razy więcej. Uderzono w bębny i generał Adam von Lewenhaupt powiódł swoich ludzi do ataku na pozycje rosyjskie. W ciagu godziny szwedzka piechota została jednak zmiażdżona przez przeważające siły wroga. Podobny los spotkał znaczną część szwedzkiej kawalerii. Stało się tak dlatego, że Szwedom przez cały czas bitwy nie udało się zebrać w jednym miejscu większej liczby szwadronów. Jazda prawego skrzydła została rozbita przez kawalerię rosyjska, która uderzyła od strony feralnych redut. Natomiast szwadrony lewego skrzydła, które sukcesywnie wychodziły $z$ bagna, natychmiast ruszały do boju i ginęły w nierównej walce $z$ piechotą i jazdą wroga. Rozbita armia szwedzka rzuciła się do panicznej ucieczki. Żeby zaś dopełnić dzieła zniszczenia, wkrótce po tym, jak pobite wojska Karola XII rozpoczęły paniczny odwrót, garnizon Połtawy dokonał wypadu i opanował szwedzkie okopy i reduty usypane w sassiedztwie twierdzy ${ }^{18}$.

Karol XII, który ze względu na swój stan zdrowia nie miał żadnego wpływu na przegranej przebieg batalii, uszedł $z$ pola walki do Puszkarewki, gdzie znajdował się szwedzki tabor i gdzie zgromadziło się około 3000 żołnierzy, którzy także umknęli przed Rosjanami. Armia szwedzka ruszyła do bitwy pod Połtawą w sile około 17 tys. ludzi. Reszta pozostała w okopach i w taborze. Ponadto kilka regi-

18 Por. F.G. Bengts son, op. cit., s. 360-372; Z. Anusik, Karol..., s. 255-264; P. From, op. cit., s. 338-352 (w całym opisie batalii pod Połtawa autor ten wyolbrzymia rolę półprzytomnego Karola XII, który jego zdaniem miał podejmować kluczowe decyzje i narzucać swoją wolę feldmarszałkowi Rehnsköldowi); J. Wi mm er, op. cit., s. 340-341 (tu jednak bardzo uproszczony i daleki od rzeczywistości opis bitwy); W. S e rczyk, op. cit., s. 129-135 (tu szereg bardzo istotnych nieścisłości. Z narracji autora zdaje się też wynikać, że Karol XII osobiście dowodził swoją armia). 
mentów rozłożono wzdłuż Worskli od Połtawy do Perewołocznej. Na polu bitwy zostało niemal 7000 zabitych żołnierzy szwedzkich. Około 2800 Szwedów (w tym feldmarszałek Rehnsköld) dostało się do niewoli. W sumie więc Karol stracił blisko 10 tys. ludzi. Ponad 7 tys. jego żołnierzy przeżyło jednak bitwę. Jeśli jednak doliczymy te oddziały, które nie brały udziału w walce, to okaże się, że nazajutrz po klęsce król Szwecji miał pod swoimi rozkazami około 18 tys. ludzi (wliczając w to Kozaków Mazepy). Nie wszystko było więc jeszcze stracone i można było pomyśleć o wycofaniu pobitej armii na Krym. Co ciekawe, wymarsz Szwedów z Puszkarewki odbył się zgodnie $z$ wszelkimi zasadami sztuki wojennej. Przodem ruszył tabor $z$ artylerią, a za nim główna część armii osłaniana przez straż tylną. Król jednak goraczkował i prawdopodobnie nie miał świadomości tego, co się wokół niego dzieje. Dlatego też Szwedzi minęli trzy dogodne brody na Worskli, gdzie mogli skręcić w kierunku tatarskich stepów, i 11 lipca doszli do Perewołocznej, gdzie spodziewali się przeprawić przez Dniepr. Okazało się jednak, że promów i łodzi starczy tylko dla 3000 ludzi. Karol podją więc decyzje o odłączeniu się od swoich żołnierzy. On sam udać się miał do Turcji, podczas gdy reszta armii, po sforsowaniu Worskli, miała podjąc marsz w kierunku Krymu. Lewenhupt, któremu król powierzył dowództwo nad armią, obiecał, że skrupulatnie wypełni wszystkie jego rozkazy. Noca 11 lipca Karol XII wraz z towarzyszącymi mu ludźmi (połowę $z$ nich stanowili Kozacy Mazepy i Zaporożcy) przeprawił się przez Dniepr i ruszył w stronę Oczakowa. W Perewołocznej pozostał generał Adam von Lewenhaupt $z$ armia liczacca ponad 16 tys. żołnierzy. Wczesnym rankiem 12 lipca 1709 r., kiedy armia szwedzka szykowała się do wymarszu, pod Perewołoczną pojawił się Aleksandr Mienszykow z oddziałem kawalerii liczącym około 9 tys. żołnierzy. Lewenhaupt nie podjął nawet próby stawienia oporu. Ostatecznie też skapitulował bez jednego wystrzału. Do rosyjskiej niewoli dostało się 1161 szwedzkich oficerów oraz 13138 podoficerów i żołnierzy. Jedynie nieliczni spośród nich wrócili po latach do swojej ojczyzny ${ }^{19}$.

Odpowiadajac na postawione w tytule tego artykułu pytanie, stwierdzić trzeba, że tak naprawdę Szwedzi nie mogli wygrać bitwy

19 Por. Z. Anusik, Karol..., s. 264-279; F.G. Bengts s on, op. cit., s. 373-387; P. From, op. cit., s. 352-402; W. Serczyk, op. cit., s. 135-137 (tu obraz wydarzeń pod Perewołoczną znacznie odbiegający od relacji uczestniczących w nich Szwedów). 
pod Połtawą. Abstrahując od wszystkich błędów popełnionych przez szwedzkich dowódców w trakcie trwania tej batalii, było ich po prostu zbyt mało. Armia rosyjska miała ponad dwukrotna przewage liczebna oraz ogromna przewage siły ognia. Nie zawiedli również dowódcy Piotra I oraz jego żołnierze. Trudno powiedzieć, jak potoczyłaby się bitwa, gdyby Karol XII mógł osobiście dowodzić swoja armia. Los jednak nie dał mu takiej szansy. Okazja do rozstrzygnięcia losów wojny została zaprzepaszczona przez króla Szwecji w 1708 r. Trudno jednak obwiniać go za zła pogodę i fatalny stan dróg na terenach, gdzie przyszło mu prowadzić wojnę. Nie było również wina szwedzkiego króla to, że Rosjanie konsekwentnie stosowali taktykę „spalonej ziemi”. Od lata 1708 r. nieszczęście za nieszczęściem spadało na Szwedów bez jakiegokolwiek udziału Piotra czy też jego żołnierzy. Kampania 1709 r. rozstrzygnęła się zaś w chwili, kiedy Karol został postrzelony w stopę. To przesądziło zarówno o wyniku bitwy pod Połtawa, jak i o kapitulacji armii szwedzkiej pod Perewołoczna. Warto przy tym zwrócić uwage na to, że rozmiary tej ostatniej katastrofy zdecydowanie przewyższyły rozmiary zwycięstwa odniesionego przez Piotra I pod Połtawą.

\section{Bibliografia}

\section{$\dot{Z}_{\text {RÓDEA DRUKOWANE }}$}

Adlerfelt G., Leben Karls des Zwölften, König von Schweden, Frankfurt-Leipzig 1740. Fänrik Robert Petrés dagbok 1702-1709, [w:] Karolinska krigares dagböcker, del. 1, Lund 1901, s. 1-284.

Löjtnant Joachim Matthiae Lyths dagbok 1703-1722, [w:] Karolinska krigares dagböcker, del. 2, Lund 1902, s. 1-99.

Nordberg J.A., Histoire de Charles XII, Roi de Suéde, t. II, La Haye 1748.

On the Eve of Poltava: The letters of Ivan Mazepa to Adam Sieniawski, 1704-1708, ed. O. Subtelny, New York 1975.

Otwinowski E., Dzieje Polski pod panowaniem Augusta II od roku 1696-1728, Kraków 1849.

Rakowski W., Pamiętniki, wyd. E. Piotrowski, Żytomierz 1860.

Zawisza K., Pamiętniki, wyd. J. Bartoszewicz, Warszawa 1862.

\section{OpRacowania}

Anusik Z., Fenomen Iwana Mazepy $w$ historiografii polskiej XIX $i$ XX w., [w:] Mity $i$ stereotypy $w$ dziejach Polski $i$ Ukrainy $w$ XIX $i$ XX wieku, red. A. Czyżewski, R. Stobiecki, T. Toborek, L. Zaszkilniak, Warszawa-Łódź 2012, s. 224-248. 
Anusik Z., Karol XII, Wrocław-Warszawa-Kraków 2006.

Bengtsson F.G., The life of Charles XII king of Sweden 1697-1718, London 1960. From P., Klęska pod Połtawa. Kampania Karola XII w Rosji w latach 1707-1709, Zabrze 2010.

Hallendorff C., Karl XII och Lewenhaupt år 1708, Uppsala 1902.

Hjelmquist F., Kriget $i$ Finland och Ingermanland 1707 och 1708, Lund 1909.

Konopczyński W., Polska a Szwecja. Od pokoju oliwskiego do upadku Rzeczypospolitej 1660-1795, Warszawa 1924.

Sarauw C., Die Feldzüge Karl's XII: Ein quellenmässinger Beitrag zur Kriegsheschichte und Kabinetpolitik Europa's im XVIII. Jahrhundert, Leipzig 1881.

Serczyk W., Połtawa 1709, Warszawa 1982.

Stille A., Carl XII:s fälttågsplaner 1707-1709, Lund 1908.

Tielpuchowski B., Siewiernaja wojna 1700-1721, Moskwa 1946.

Wimmer J., Wojsko Rzeczypospolitej w dobie wojny pótnocnej (1700-1717), Warszawa 1956.

ZBigniew ANusiK

UNIVERSITY OF LODZ

\title{
Why did the Swedes lose the battle of Poltava? The nature against the Swedish army during the campaigns of 1708 and 1709
}

\begin{abstract}
$\mathrm{T}$ he article presents the course of actions undertaken by the Swedish army in the years 1708 and 1709. Both campaigns were directed against Russia, and the strategic goal outlined by the ruler of Sweden - Charles XII was to seize Moscow. At the end of 1708, however, the Swedish army was not in the foreground of the tsar's capital, but in Ukraine, on the left bank of Dnepr. The following year the Swedes fought the battle of Poltava, which ended with their defeat. The author tries to answer the question, why did this happen? When discussing the path of Charles XII to the Poltava battlefield, he pays attention primarily to natural and objective factors (weather, surface shape, natural obstacles etc.) on which the King of Sweden had no influence. In the author's opinion, these was this factors that largely influenced the fact that the Swedish army stood to the battle of Poltava significantly weakened and with a very little chance to win.
\end{abstract}

Keywords: Charles XII, Great Northern War, campaigns of 1708 and 1709, expedition to Moscow, battle of Poltava, weather and natural conditions. 